\title{
AERIAL SOLAR COLLECTOR USAGE IN DRYING TECHNOLOGIES OF MEDICINAL AND SPICE PLANTS
}

\author{
Ausra Cipliene, Egidijus Zvicevicius, Algirdas Raila \\ Aleksandras Stulginskis University, Lithuania \\ ausra.cipliene@asu.lt, egidijus.zvicevicius@asu.lt, algirdas.raila@asu.lt
}

\begin{abstract}
In Lithuania small farmers more often are focusing on alternative plant production like medicinal and spice plants. Processing of medicinal-spice raw material cannot be performed without the drying process. It is known that a drying process of medicinal and spice plants takes up to 50-70\% of all its production costs. The aim of this research was to determine the possibilities of decreasing the energy consumption by using solar energy while drying medicinal and spice plants. In the medicinal plant dryer with $131 \mathrm{~m}^{2}$ air solar collector integrated into the roof of the building, solar irradiance was $453.3 \pm 317.9 \mathrm{~W} \cdot \mathrm{m}^{-2}$ and the ambient air temperature of $23.1 \pm 3.8^{\circ} \mathrm{C}$ from 10:00 a.m. to $6: 00 \mathrm{p} . \mathrm{m}$. maintained at $31.3 \pm 3.8^{\circ} \mathrm{C}$ temperature of the drying agent. It means that external solar collector, within 8 hours, converts $130.21 \pm 37.3 \mathrm{kWh}$ of thermal energy. The largest solar collector efficiency factor was 0.6 , while comparative air flow from 1.8 to $2.0 \mathrm{~kg} \cdot \mathrm{s}^{-1}$ was moving over the panels. It is possible to convert $15235 \mathrm{kWh}$ of thermal energy as well as to reduce about $64 \%$ of fossil fuel or biofuel consumption and the amount of environmental emissions while using an aerial solar collector in preparation of the drying agent during the harvesting period of medicinal-spice plants.
\end{abstract}

Keywords: aerial solar collector, solar radiation, drying, renewable energy.

\section{Introduction}

Drying process is a technological operation in agriculture crop sector demanding the most energy of all operations. Although its thermal efficiency is only $25-50 \%$, this process takes up to $15 \%$ of total energy consumption in the world [1]. Arata et al. states that concentrated energy costs can be reduced by $27-80 \%$, if solar conversion energy systems with $40 \%$ of efficiency could be used in drying technologies [2].

Solar conversion energy systems are not used practically in drying technologies in Lithuania. This is because the amount of obtained solar energy is almost 2 times less, about $1000-1300 \mathrm{kWh} \cdot \mathrm{m}^{-2}$ per year, compared with the countries located in tropical and subtropical climate zones [3]. Also, the harvest time of prevailing traditional farming in Lithuania is quite short and late. Recently, however, since small farmers are hardly able to compete with big farms, they started developing a nontraditional crop production, in which the medicinal herb plantations attracted a lot of attention. A large diversity of species allows farmers to create a diverse range of different medicinal herb-spice collections. Also, the period of harvesting and preparation can be allocated within an entire summer season ranging from April to September.

The moisture content in medicinal plant raw material is up to $80 \%$. After the harvesting process the most important technological operation is to reduce the moisture content of plants raw material down to 8-12\%. To evaporate the water inside of the plants requires a plenty of thermal energy and its production costs takes up a largest part in the production cost of medicinal plant raw materials. Most scientists claim that the temperature of the drying agent and ventilation intensity has the biggest influence on the drying time [4-6]. It is noted that the temperatures of the drying agent also influence the losses of biologically active substances [7]. Per scientific studies the colour of most medicinal plant raw materials and active substances (essential oils, phenolic compounds including caffeic acid derivatives) are responsive to high temperature of drying agents $[8 ; 9]$. The temperature of the drying agent is commonly recommended to be between 30 to $50^{\circ} \mathrm{C}$ [8; 9], while in Lithuania the average temperature in April-September ranges from 6.5 to $17^{\circ} \mathrm{C}$. It means that energy is required to heat up the drying agent.

To reduce costs and environmental impact while developing cleaner production technologies, solar energy can be used in preparation of the drying agent. Aerial solar collectors are commonly used in drying technologies that require relatively low temperature of $60^{\circ} \mathrm{C}$ [10-12]. The efficiency of the collector is highly influenced by the structure. It is recommended to install collectors with a transparent cover, if ambient air must be heated up above $10^{\circ} \mathrm{C}[13,14]$. The researchers also found that the collector's efficiency increases up to $10-15 \%$, if air flows on both sides of the absorber compared with the collectors, where air flows only on one side of the absorber [15; 16]. Quite a lot of 
different types of dryers were tested around the world with different solar energy conversion systems like chimney or greenhouse type dryers and dryers with integrated solar collectors, but most of these dryers were tested in tropical and subtropical climate zones $[17 ; 18]$.

The aim of this research was to determine the possibilities of decreasing the energy consumption by using solar energy while drying medicinal and spice plants.

\section{Materials and methods}

Studies were carried out in a medicinal-spice plant dryer, which is located in the geographical $54^{\circ} 9^{\prime} 7.76$ " N latitude and 243'16.94" E longitude. An aerial $131 \mathrm{~m}^{2}$ of area solar collector is integrated into a roof of a dryer facing south with a tilt angle of $45^{\circ}$ Fig. 1. The aerial solar collector consists of a thick $10 \mathrm{~mm}$ transparent polycarbonate cover 3 (optical permeability coefficient $\tau=0.82$ - 0.89) and a thick $10 \mathrm{~mm}$ sheet of steel painted in black - absorber 4 (absorption ability $\alpha=0.94-$ 0.98). Air flows along both sides of the absorber downwards.

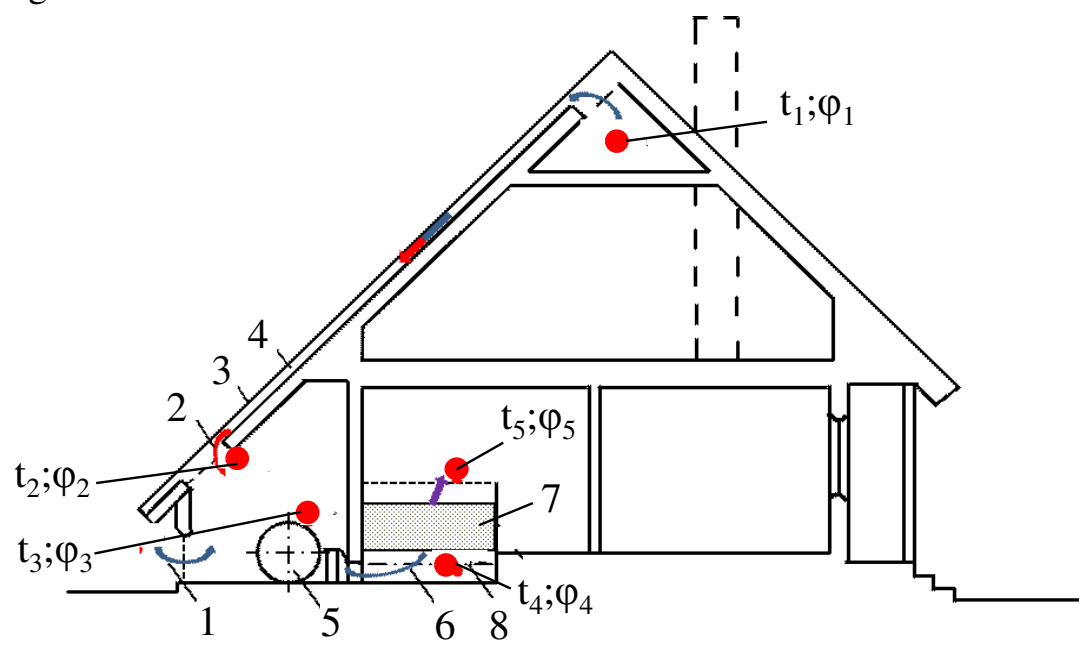

Fig. 1. Principal scheme of medicinal and spice plant raw materials dryer with aerial solar collector: 1 - outdoor air flow; 2 - heated air flow; 3 - transparent cover; 4 - absorber; 5 - fan; 6 under sieve cavity; 7 - garner; 8 - floor of the garner; $t_{0}, \varphi_{0}, t_{1}, \varphi_{1}, t_{2}, \varphi_{2}, t_{3}, \varphi_{3}, t_{4}, \varphi_{4}, t_{5}, \varphi_{5}-$ temperature and humidity sensors

The solar collector with the air flow converts the obtained solar radiation energy into heat energy and transfers it to the air flow inside the collector. Preheated air flow enters a block of fans through 21 $(0,195 \times 0,245 \mathrm{~m})$ holes in a wall of the aerial solar collector. The air flow is created by four high pressure and powerful air flow fans; they allow setting the required air supply to each bin, depending on the dried raw material. The experimental research comprised measurements of the following parameters: air temperature and relative humidity (AHLBORN FH A646, accuracy $t \pm 0.1{ }^{\circ} \mathrm{C}, \varphi \pm 2 \%$ ), solar irradiance on the collector surface (AHLBORN FLA 613 GS, absolute accuracy < $10 \%)$. Data were recorded periodically every $10 \mathrm{~min}$ and stored in memory of the secondary device ALMEMO 5690-2. Sensor arrangement is shown in Fig. 1.

Additionally, using $H H-600$ Series temperature-anemometer Omegaflo, Model $615 \mathrm{M}\left( \pm 0.1 \mathrm{~m} \cdot \mathrm{s}^{-1}\right)$ the air flow velocity was measured at the holes in a wall of the aerial solar collector. Detailed specifications of measurement devices are presented in Table 1. Air and heat flows were calculated according to the results of the measurements obtained.

During the research, the necessary quantity of energy to prepare the drying agent was determined. Also, comparative environmental assessment calculations were carried out. During the period of the research, the assessment of greenhouse gas emissions was carried out using other energy sources to produce thermal energy, i. e. electricity (produced by Lietuvos elektrinè, Plc), natural gas, diesel and wood fuels. Comparative calorific values used in the calculations were taken from the Fuel and Energy Balance 2013 reports of Statistics Lithuania and are presented in Table 2. Emission into the environment $\left(\mathrm{CO}_{2}, \mathrm{SO}_{2}\right.$ and $\left.\mathrm{NO}_{\mathrm{x}}\right)$ is calculated using the standard emission factors [19]. 
Specifications of measurement devices

\begin{tabular}{|c|c|c|c|}
\hline Instrumentation & Measurements & Range & Accuracy \\
\hline $\begin{array}{c}\text { Digital temperature \& humidity } \\
\text { sensor }\end{array}$ & $\begin{array}{c}\text { Air temperature } \\
\text { Air relative } \\
\text { humidity }\end{array}$ & $\begin{array}{c}-20 \text { to }+80{ }^{\circ} \mathrm{C} \\
0-100 \%\end{array}$ & $\begin{array}{c} \pm 0.1^{\circ} \mathrm{C} \\
\pm 2 \%\end{array}$ \\
\hline $\begin{array}{c}\text { AHLBORN FH A646 } \\
\text { AHLBORN T 190-3 }\end{array}$ & Temperature & -45 to $+200^{\circ} \mathrm{C}$ & $\pm 0.1^{\circ} \mathrm{C}$ \\
\hline $\begin{array}{c}\text { Temperature anemometer } \\
\text { OMEGAFLO HH-600 Serial, } \\
\text { Model 615M }\end{array}$ & Air flow velocity & $0-30 \mathrm{~m} \cdot \mathrm{s}^{-1}$ & $\pm 0.1 \mathrm{~m} \cdot \mathrm{s}^{-1}$ \\
\hline $\begin{array}{c}\text { Global radiation probe head } \\
\text { AHLBORN FLA 613 GS }\end{array}$ & Solar irradiance & $\begin{array}{c}0 \text { to approx. } 1200 \\
\mathrm{~W} \cdot \mathrm{m}^{-2}\end{array}$ & $\begin{array}{c}\text { Absolute } \\
\text { accuracy }<10 \%\end{array}$ \\
\hline Data recorder & $\begin{array}{c}\text { 80 Measuring } \\
\text { channels via } \\
\text { selector }\end{array}$ & $\begin{array}{c}\text { Sufficient for } \\
400.000 \text { values, } \\
\text { linear or ring } \\
\text { memory }\end{array}$ & - \\
\hline ALMEMO 5690-2 & \multicolumn{2}{|c}{} \\
\hline
\end{tabular}

Standard emission factors of different energy sources, $\mathrm{kg} \cdot \mathrm{MWh}^{-1}[19]$

Table 2

\begin{tabular}{|l|c|c|c|}
\hline \multirow{2}{*}{ Type of energy source } & \multicolumn{3}{|c|}{ Standard emission factors, $\mathbf{~ k g} \cdot \mathbf{M W h}^{-\mathbf{1}}$} \\
\cline { 2 - 4 } & $\mathrm{CO}_{2}$ & $\mathrm{SO}_{2}$ & $\mathrm{NO}_{\mathbf{x}}$ \\
\hline Electric power & 626.0 & 0.450 & 0.95 \\
\hline Diesel & 280.8 & 0.351 & 0.540 \\
\hline Natural gas & 204.8 & 0.001 & 0.288 \\
\hline Wood fuel* & $367.2(0)$ & 0.468 & 0.360 \\
\hline
\end{tabular}

* wood releases the same amount of $\mathrm{CO}_{2}$ while naturally disintegrating, so the burning of wood does not increase the amount of $\mathrm{CO}_{2}$ in the atmosphere

\section{Results and discussion}

Lithuania is located on the northern part of temperate zone along with prevailing western humid air transfer and changeable weather. Countries located within the temperate zone on average reach up to $4000 \mathrm{MJ} \cdot \mathrm{m}^{-2}$ of solar radiation in total: $60 \%$ consist of dispelled energy and $40 \%$ consist of direct solar radiation energy [20].

After a carried-out analysis of the meteorological data it was determined that the highest quantity of 1.49-5.4 $\mathrm{kWh} \cdot \mathrm{m}^{-2}$ of solar energy per day in Lithuania, Poland and Germany occurs between April and September, in other words during the period of harvesting and preparation of medicinal and spice plants (Fig. 2).

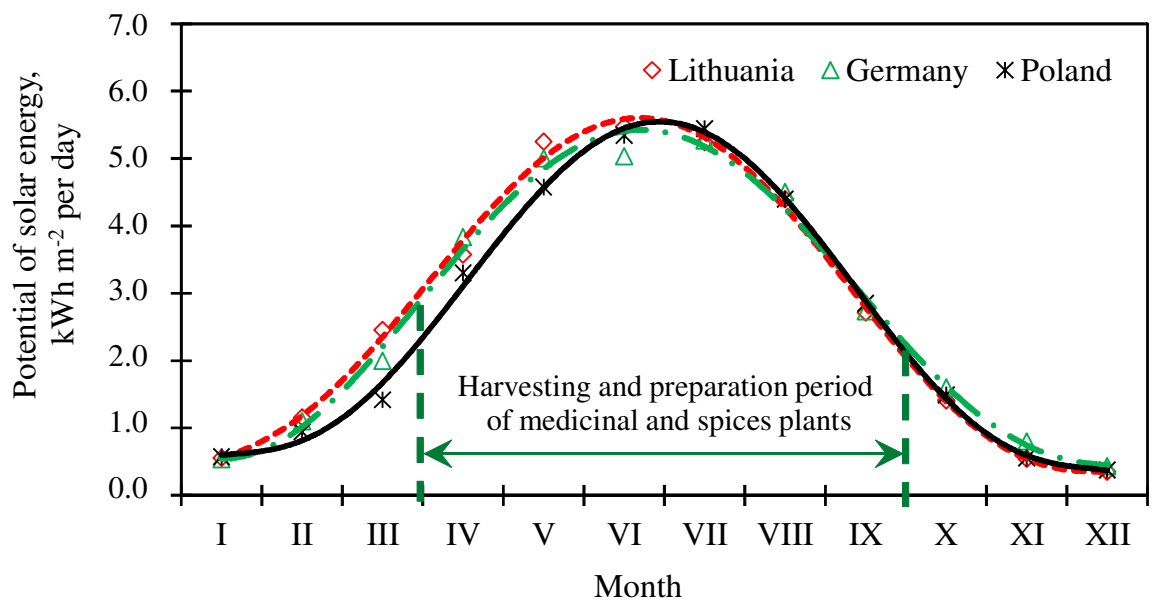

Fig. 2. Potential of solar energy in Lithuania, Germany and Poland 
The highest quantity of solar energy in Lithuania occurs in June at $4.8 \mathrm{kWh} \cdot \mathrm{m}^{-2}$ per day, in Poland and Germany this number is $0.5 \mathrm{kWh} \cdot \mathrm{m}^{-2}$ and $0.38 \mathrm{kWh} \cdot \mathrm{m}^{-2}$ bigger per day during the same time respectively. The lowest quantity of solar radiation during the harvesting and preparation period of medicinal and spice plants occurs in April and September respectively: 3.57 and $2.71 \mathrm{kWh} \cdot \mathrm{m}^{-2}$ in Lithuania, 3.71 and $2.85 \mathrm{kWh} \cdot \mathrm{m}^{-2}$ in Poland, 3.83 and $2.91 \mathrm{kWh} \cdot \mathrm{m}^{-2}$ in Germany per day. During the period between April and September not only the highest intensity of solar radiation energy prevails in temperate zone countries, but there is also the highest quantity of rainfall. There are 11.2 \pm 0.91 days on average in Lithuania that contain more than $1 \mathrm{~mm}$ of rainfall during the period between April and September [20]. Both Poland and Germany have less number of such days with $8.3 \pm 0.95$ and $9.5 \pm 0.75$ respectively [21;22].

During the experimental studies an average daily temperature of $19.8 \pm 4.0^{\circ} \mathrm{C}$ and relative humidity levels of $70.5 \pm 9.6 \%$ were recorded (Fig. 3). Maximum values of solar irradiance ranged from 1:00 p.m. to 3:00 p.m. hours, and during individual days during this period they ranged from $332.7 \pm 359.3$ to $722.1 \pm 410.2 \mathrm{~W} \cdot \mathrm{m}^{-2}$. On average, under such natural conditions the aerial solar collector heats the drying agent from 7.5 to $14^{\circ} \mathrm{C}$, i. e. the temperature of the drying agent supplied on the layer of medicinal and spice plant raw materials was $30.4 \pm 3.2^{\circ} \mathrm{C}$. Relative humidity levels of air decreased 1.84 times on average, i. e. relative humidity of the drying agent $-38.2 \pm 8.0 \%$.

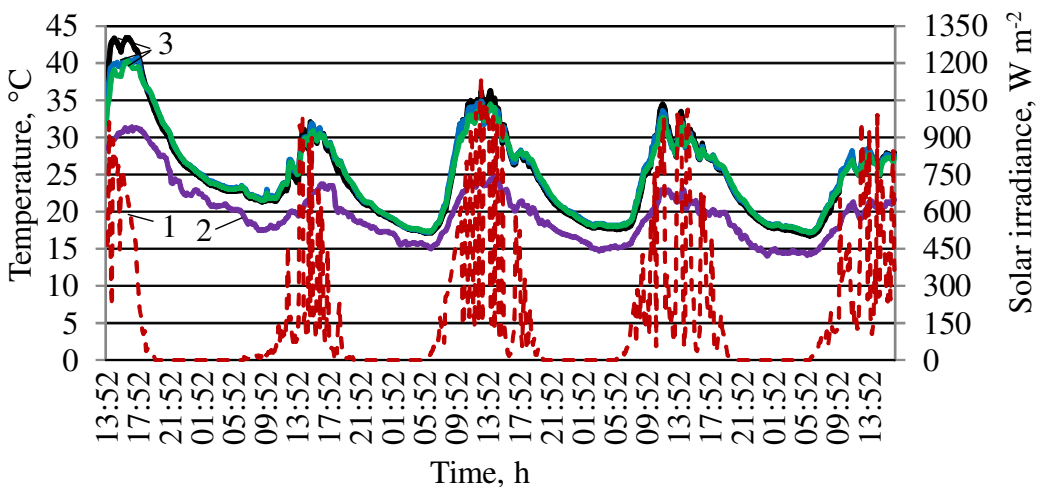

Fig. 3. Evolution of drying agent temperature through the day: $1-$ solar irradiance, $\mathrm{W} \mathrm{m}^{-2}$;

2 - surrounding air temperature, ${ }^{\circ} \mathrm{C} ; 3$ - temperature of drying agent, ${ }^{\circ} \mathrm{C}$

During the experimental studies it was determined that between 9:00 a.m. and 8:00 p.m. hours, i. e. within 11 hours, the area of $131 \mathrm{~m}^{2}$ of the aerial solar collector produces from 397.4 to $616.4 \mathrm{MJ}$ of heat respectively, when instantaneous power per one solar collector varies from $25.7 \pm 33$ to $54.6 \pm 46.5 \mathrm{~kW}$ (Fig. 4.) A convertible heat began to decline from 17-18 hours, but due to inertia of the structural elements of the collector $22.04 \pm 7.33 \mathrm{MJ}$ of heat per hour was produced for up to 20 hours.

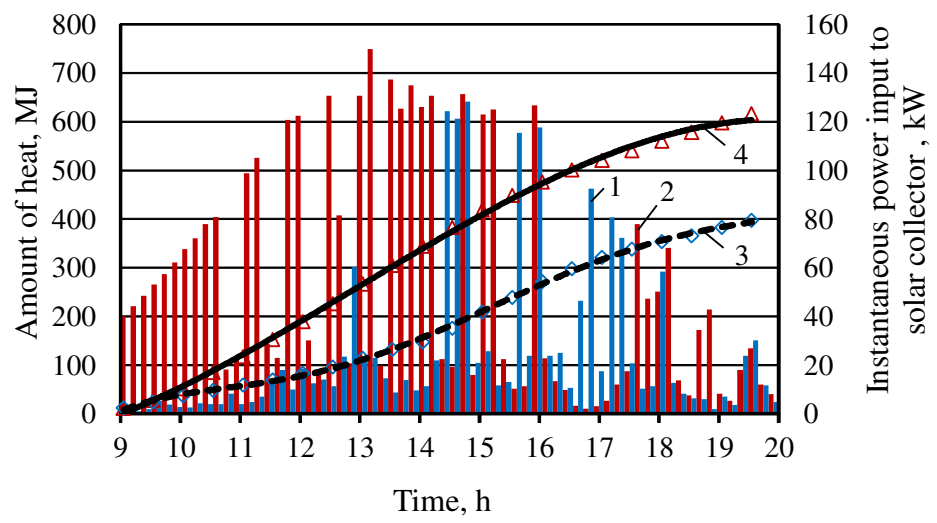

Fig. 4. Change of solar energy radiation flow, received by solar collector, and of amount of converted heat when air flow in aerial solar collector is $1.86-2.21 \mathrm{~kg} \cdot \mathbf{s}^{-1}: 1-$ instantaneous power input to solar collector (first type of day); 2 - instantaneous power input to solar collector (second type of day); 3 - converted amount of heat (first type of day); 4 - converted amount of heat

(second type of day) 
When the air flow in the solar collector varies in the range from 1.18 to $2.21 \mathrm{~kg} \cdot \mathrm{s}^{-1}$, its efficiency varies according to the logarithmic curve (Fig. 5.). The biggest efficiency coefficient of $61.82 \pm 3.25 \%$ was found, when average solar irradiance was $105.96 \pm 15.07 \mathrm{~W} \cdot \mathrm{m}^{-2}$ and the difference between temperatures of the ambient air and the air flowing out from the collector was $4.19 \pm 0.83^{\circ} \mathrm{C}$. The lowest efficiency coefficient of $16.1 \pm 0.1 \%$ was found at the time, when the ratio of the temperature difference and solar irradiance (reduced temperature difference) was the lowest, too, i. e. $0.010-0.013\left({ }^{\circ} \mathrm{C} \cdot \mathrm{m}^{2} \cdot \mathrm{W}^{-1}\right)$.

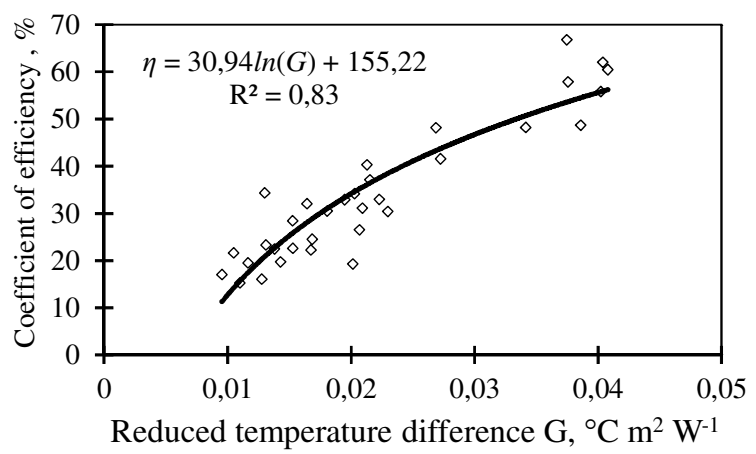

Fig. 5. Change of efficiency coefficient of aerial solar collector

During the studies, the air speed in the aerial solar collector was amended from 0.4 to $2.9 \mathrm{~kg} \cdot \mathrm{s}^{-1}$. The largest power and efficiency of the aerial solar collector was at $1.83-2.02 \mathrm{~kg} \cdot \mathrm{s}^{-1}$ (Fig. 6.). It means that at $560 \pm 50 \mathrm{~W} \cdot \mathrm{m}^{-2}$ of solar irradiance and higher than $2.02 \mathrm{~kg} \cdot \mathrm{s}^{-1}$ air flow in the collector, the air flows through the collector too fast and fails to transmit the whole extracted heat flux.

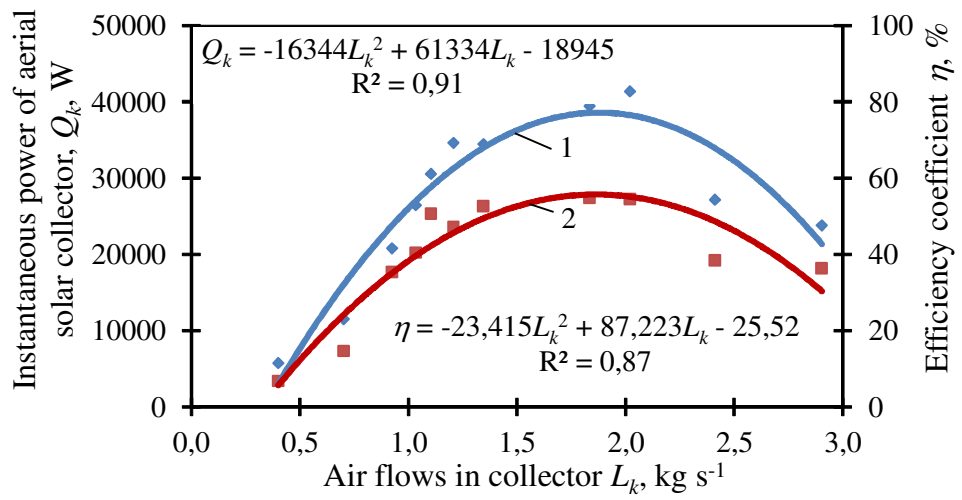

Fig. 6. Change of efficiency coefficient of aerial solar collector with different air flows in collector: 1 - instantaneous power of aerial solar collector; 2 - efficiency coefficient of aerial solar collector

In the medicinal and spice plant raw material dryer, when the average solar irradiance is $453.3 \pm 317.9 \mathrm{~W} \cdot \mathrm{m}^{-2}$, an aerial $131 \mathrm{~m}^{2}$ solar collector, which is integrated into the roof of a building, raises the ambient temperature by $8^{\circ} \mathrm{C}$ on average during a period from 10:00 a.m. to 6:00 p.m. hours, i. e. the average temperature of the drying agent reaches up to $31.3^{\circ} \mathrm{C}$. It means that during 8 hours the solar collector produces $130.21 \pm 37.3 \mathrm{kWh}$ of thermal energy.

Due to the fact that from April to September in Lithuania there are 66 rainy days on average during the season, it is estimated that the aerial solar collector converts about $15235 \pm 4364 \mathrm{kWh}$ of thermal energy throughout the period of harvesting and preparation of medicinal and spice plants. That amount of thermal energy can be obtained after consuming $15.24 \pm 4.36 \mathrm{kWh}$ of electricity or burning in an amount of $1532 \pm 4 \mathrm{~kg}$ of oil, $1819 \pm 52 \mathrm{~m}^{3}$ natural gas or $3254 \pm 932 \mathrm{~kg}$ of wood fuel. However, with the obtained thermal energy the amount of gases containing a negative impact on the environment gets released into the environment, i. e. $\mathrm{CO}_{2}, \mathrm{NO}_{\mathrm{x}}, \mathrm{SO}_{2}$. After comparative calculations were carried out, it was found out that to receive such amount of thermal energy, while using usual energy sources, an amount of $(3,12-9,54) \cdot 10^{3} \mathrm{~kg}$ of $\mathrm{CO}_{2}, 0,015-7,13 \mathrm{~kg}$ of $\mathrm{SO}_{2}$ and $5,27-14,47 \mathrm{~kg}$ of $\mathrm{NO}_{\mathrm{x}}$ could be released into the environment. 


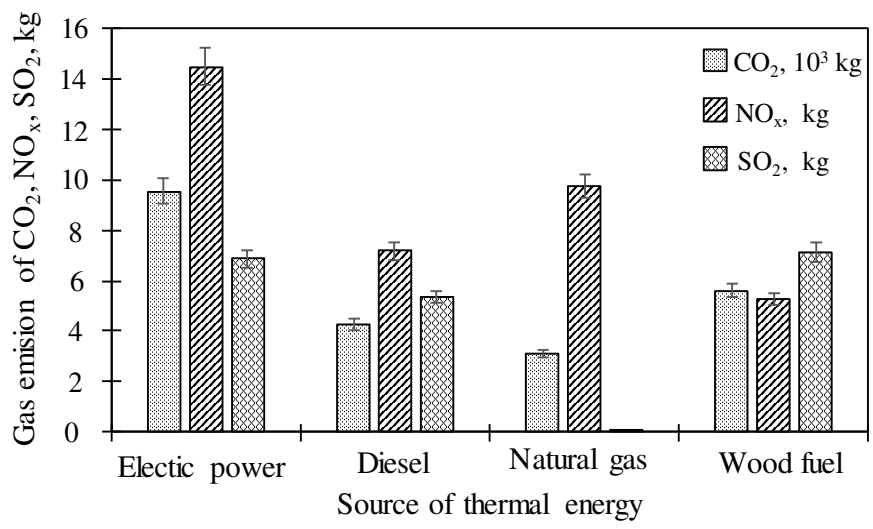

\section{Fig. 7. $\mathrm{CO}_{2}, \mathrm{NO}_{\mathrm{x}}$ and $\mathrm{SO}_{2}$ emissions released in obtaining $15235 \pm 4364 \mathrm{kWh}$ of thermal energy from different energy sources}

In summary, the carried-out studies suggest that effective usage of solar energy conversion systems for drying of medicinal-spice plants allows to essentially decrease the usage of fossil fuels as well as lower the impact on the environment. In the temperate climate zone the amount of energy consumption and environmental emissions reduce for about $64 \%$, if in the medicinal-spice plant dryer an integrated aerial solar collector is used to prepare the drying agent.

\section{Conclusions}

1. During the period of harvest-preparation for medicinal and spice plants, Lithuania has about $50 \%$ of the annual rainfall, and one month has an average of 10 rainy days. Solar radiation intensity is $4.1 \pm 0.8 \mathrm{kWh}$ per day. Lithuanian natural conditions are close to Poland's and Germany's natural conditions.

2. In the medicinal plant dryer with $131 \mathrm{~m}^{2}$ air solar collector integrated into the roof of the building, solar irradiance was $453.3 \pm 317.9 \mathrm{~W} \cdot \mathrm{m}^{-2}$ and the ambient air temperature of $23.1 \pm 3.8^{\circ} \mathrm{C}$ from 10:00 a.m. to 6:00 p.m. maintained at $31.3 \pm 3.8^{\circ} \mathrm{C}$ temperature desiccant. It means that the external solar collector, within 8 hours, converts $130.21 \pm 37.3 \mathrm{kWh}$ of thermal energy. The largest air solar collector efficiency factor was 0.6, while comparative air flow from 1.8 to $2.0 \mathrm{~kg} \cdot \mathrm{s}^{-1}$ was moving over the panels.

3. It is possible to convert $15235 \mathrm{kWh}$ of thermal energy as well as to reduce about $64 \%$ of fossil fuel or biofuel consumption and the amount of environmental emissions, while using an aerial solar collector in preparation of the drying agent during the harvesting period of medicinal-spice plants. In other words, the release of gases such as $\mathrm{CO}_{2}, \mathrm{SO}_{2}, \mathrm{NO}_{\mathrm{x}}$ into the environment would decrease from 3.12 to $9.54 \mathrm{t}$, from 0.015 to 7.13 and from 5.27 to $14.47 \mathrm{~kg}$ respectively.

\section{References}

[1] Chua K.J., Mujumdar A.S., Hawlader M.N.A., Chou S.K., Ho J.C., Batch drying of banana pieces - effect of stepwise change in drying air temperature on drying kinetics and product colour. Food Research International, vol. 34, 2001, pp. 721-731.

[2] Arata A., Sharma V.K., Spagna G., Performance evaluation of solar assisted dryers for low temperature drying application - II. Experimental results. Energy Conversion and Management, vol. 34, 1993, pp. 417-426.

[3] Čiplienė A., Novošinskas H., Raila A., Zvicevičius E., Usage of hybrid solar collector system in drying technologies of medical plants. Energy Conversion and Management, vol. 93, 2015, pp. 399-405.

[4] Azzouz S., Guizani A., Jomaa W., Belghith A., Moisture diffusivity and drying kinetic equation of convective drying of grapes. Journal of Food Engineering, vol. 55, 2002, pp. 323-330.

[5] Boughali S., Benmoussa H., Bouchekima B., Mennouche D., Bouguettaia H., Bechki D., Crop drying by indirect active hybrid solar - Electrical dryer in the eastern Algerian Septentrional Sahara. Solar Energy, vol. 83, 2009, pp. 2223-2232.

[6] Chen W., Qu M., Analysis of the heat transfer and airflow in solar chimney drying system with porous absorber. Renewable Energy, vol. 63, 2014, pp. 511-518. 
[7] Argyropoulos D., Müller J., Changes of essential oil content and composition during convective drying of lemon balm (Melissa officinalis L.). Industrial Crops and Products, vol. 52, 2014, pp. 118-124.

[8] Kim H., Durance T.D., Scaman C.H., Kitts D.D., Retention of caffeic acid derivatives in dried Echinacea purpurea. Journal of Agricultural and Food Chemistry, vol. 48, 2000, pp. 4182-4186.

[9] Lin S., Sung J., Chen C., Effect of drying and storage conditions on caffeic acid derivatives and total phenolics of Echinacea Purpurea grown in Taiwan. Food Chemistry, vol. 125, 2011, pp. 226231.

[10]Fudholi A., Sopian K., Ruslan M.H., Alghoul M.A., Sulaiman M.Y., Review of solar dryers for agricultural and marine products. Renewable and Sustainable Energy Reviews, vol. 14, 2010, pp. $1-30$.

[11] Karim M.A., Hawlader M.N.A., Development of solar air collectors for drying applications. Energy Conversion and Management, vol. 45, 2004, pp. 329-344.

[12] Şevik S., Design, experimental investigation and analysis of a solar drying system. Energy Conversion and Management, vol. 68, 2013, pp. 227-234.

[13] Kalogirou S.A., Solar thermal collectors and applications. Progress in Energy and Combustion Science, vol. 30, 2004, pp. 231-295.

[14] Sodha M.S., Bansal N.K., Kumar A., Bansal P.K., Malik M.A.S., Solar crop drying. volume II ed., CRC Press, Boca Raton, Florida, 1987.

[15] Chamoli S., Chauhan R., Thakur N.S., Saini J.S., A review of the performance of double pass solar air heater. Renewable and Sustainable Energy Reviews, vol. 16, 2012, pp. 481-492.

[16] Forson F.K., Nazha M.A.A., Rajakaruna H., Experimental and simulation studies on a single pass, double duct solar air heater. Energy Conversion and Management, vol. 44, 2003, pp. 1209-1227.

[17] Belessiotis V., Delyannis E., Solar drying. Solar Energy, vol. 85, 2011, pp. 1665-1691.

[18] Yadav A.K., Chandel S.S., Tilt angle optimization to maximize incident solar radiation: A review. Renewable and Sustainable Energy Reviews, vol. 23, 2013, pp. 503-513.

[19] Konstantinavičiūtė I., Miškinis V., Norvaiša E., Pedišius N., Bobinaitė V., Šiltnamio efektą sukeliančių dujų nacionalinių emisijų rodiklių energetikos sektoriuje įvertinimas (Estimation of national emissions of greenhouse gases in the energy sector). Final report, 96 (2012).

[20] Galvonaitė A., Kilpys J., Karkozas J., Lietuvos klimato atlasas (Climate atlas of Lithuania), Vilnius, 2013.

[21] Deutscher Wetterdienst, Der KLIMA - Report 2009 (2010).

[22] Lorenc H., Atlas Klimatu Polski, Instytut Meteorologii i Gospodarki Wodnej, 2005. 